\title{
Spatial Distribution of the Dagger Nematode Xiphinema index and Its Associated Grapevine fanleaf virus in French Vineyard
}

\author{
L. Villate, V. Fievet, B. Hanse, F. Delemarre, O. Plantard, D. Esmenjaud, and M. van Helden
}

First, second, and fifth authors: INRA, Agrocampus Rennes, UMR1099 BiO3P (Biology of Organisms and Populations applied to Plant Protection), F-35653 Le Rheu, France; fourth and seventh authors: ENITA de Bordeaux, UMR SV (Santé Végétale), F-33170 Gradignan, France; third author: Laboratory of Nematology, Wageningen University, 6709 PD Wageningen, The Netherlands; and sixth author: INRA, UMR IBSV (Biotic Interactions and Plant Health), Equipe "Interactions Plantes-Nématodes," F-06903 Sophia-Antipolis, France.

Current address of first author: INRA-UMR BiO3P, Equipe "Biologie et Génétique des Nématodes Phytoparasites," Domaine de la Motte BP 35327, 35653 Le Rheu, France.

Accepted for publication 28 April 2008.

\begin{abstract}
Villate, L., Fievet, V., Hanse, B., Delemarre, F., Plantard, O., Esmenjaud, D., and van Helden, M. 2008. Spatial distribution of the dagger nematode Xiphinema index and its associated Grapevine fanleaf virus in French vineyard. Phytopathology 98:942-948.

The nematode Xiphinema index is, economically, the major virus vector in viticulture, transmitting specifically the Grapevine fanleaf virus (GFLV), the most severe grapevine virus disease worldwide. Increased knowledge of the spatial distribution of this nematode, both horizontally and vertically, and of correlative GFLV plant infections, is essential to efficiently control the disease. In two infested blocks of the Bordeaux vineyard, vertical distribution data showed that the highest numbers of

individuals occurred at 40 to $110 \mathrm{~cm}$ depth, corresponding to the two layers where the highest densities of fine roots were observed. Horizontal distribution based on a $10 \times 15 \mathrm{~m}$ grid sampling procedure revealed a significant aggregative pattern but no significant neighborhood structure of nematode densities. At a finer scale $(\approx 2 \times 2 \mathrm{~m})$, nematode sampling performed in a third block confirmed a significant aggregative pattern, with patches of 6 to $8 \mathrm{~m}$ diameter, together with a significant neighborhood structure of nematode densities, thus identifying the relevant sampling scale to describe the nematode distribution. Nematode patches correlate significantly with those of GFLV-infected grapevine plants. Finally, nematode and virus spread were shown to extend preferentially parallel to vine rows, probably due to tillage during mechanical weeding.
\end{abstract}

Among the virus vectors of the Longidoridae family, the nematode Xiphinema index has the greatest economic impact in European vineyards, as it transmits the Grapevine fanleaf virus (GFLV) $(8,15,21,35)$. GFLV is transmitted in the soil, grapevine to grapevine by the nematode feeding on growing root tips; while feeding, the nematode acquires GFLV particles and retains them at specific sites within its feeding apparatus (37).

Despite measures to control GFLV spread, this disease remains problematic in vineyards where it is established (3). Control strategies used to rely mainly on soil disinfection to reduce $X$. index populations between two successive grapevine crops (32, $35)$, but this is effective only in the upper layers $(0$ to $40 \mathrm{~cm})$ of the soil (40). Nematodes can survive and retain GFLV in unfavorable conditions for many years (12). Complete virus control is very difficult as a few surviving viruliferous nematode individuals may be sufficient to infect grapevine plants and re-initiate virus spread (35). The use of chemical nematicides is prohibited in an increasing number of countries, due to their adverse environmental effects (2). Prolonged fallow periods (at least 7 years) following careful removal of root debris is, nowadays, the only alternative to effectively reduce $X$. index populations (15). Systemic herbicide can be used on GFLV-infected grapevines before uprooting them, to destroy roots which could serve as virus reservoirs thus delaying contamination of replants (13). Because of the limits of these methods, developing alternative control strategies is essential. Among them, plants with an antagonistic

Corresponding author: L. Villate; E-mail address: laure.villate@ rennes.inra.fr

doi:10.1094/PHYTO-98-8-0942

(C) 2008 The American Phytopathological Society effect on $X$. index populations are being investigated $(1,5)$, both before replanting vines and in intercropping.

To estimate the efficiency of any control method, the density of nematodes must be described precisely. A better understanding of the spatial distribution of individuals, both horizontally and vertically, is essential to accurately build sampling strategies and experimental designs. Spatial distribution of individuals is one of the most characteristic ecological properties of animal species (39). In particular, the three dimensional distribution of nematode species is determined by soil texture, soil moisture (drainage patterns), spacing and morphology of plant roots, nematode feeding strategy, and life cycle, as well as initial introduction and field history (4). The distribution of $X$. index in the soil is not clearly defined. In highly infected fields, this species is known to reside deeply in the soil, and has been found at a depth of $3.5 \mathrm{~m}$ (41). However, high densities are recorded at intermediary depths ranging from 10 to $30 \mathrm{~cm}$ to $90 \mathrm{~cm}$ depending on soil characteristics and management $(11,14,16,20,30)$. $X$. index is detected in soils varying from light to heavy, with higher population densities in light rather than in heavy soils $(16,45)$, although some studies suggest the opposite (14). As nematode numbers could depend on soil characteristics and may be density-dependent (45), details about their 3D distribution and environmental factors involved in their repartition are needed.

The first aim of this work was to precisely describe the spatial distribution of $X$. index in the grapevine block so as to infer diffusion processes of populations in the field. Questions tackled included: What size must the grid have for the sampling? Are patches independent one from another (neighborhood structure)? Is the spread of individuals homogeneous and continuous? Are there preferential directions of dispersal? The other aim was to determine whether nematode patches are related with those of 
GFLV-infected grapevine plants. Results are expected to be used to design a protocol in order to evaluate the effect of growing putative antagonistic plants during the fallow period, and to better control vector dispersal and virus spread for long-term management of GFLV plant disease.

\section{MATERIALS AND METHODS}

The study was conducted in the Bordeaux vineyard (France), in three GFLV-infected grapevine blocks (plots 1 to 3). Data about their location, surface, age, crop status, grapevine variety, rootstock, and percentage of enzyme-linked immunosorbent assay (ELISA) GFLV infection are reported in Table 1. Two complementary aspects were considered: (i) vertical nematode distribution was assessed in one subplot within each of plots 1 and 2 (55 and $20 \mathrm{~m}^{2}$ ); (ii) horizontal nematode distribution was then assessed at the field scale in those two plots (1 ha), and at a finer scale in plot $3\left(180 \mathrm{~m}^{2}\right)$ in relation to the distribution of GFLV in grapevine plants.

Nematode extraction, identification, and counts. Nematodes were extracted from 2-liter soil samples. If the total volume of soil samples was higher, a subsample of 2 liters was randomly chosen for nematode extraction. Samples were firstly suspended and stirred in 10 liters of water; after $15 \mathrm{~s}$ of decantation, the suspension was poured through a $2.5-\mathrm{mm}$ sieve into a 35 -liter bucket, and organic material and roots retained by the sieve were eliminated. This was repeated three times. The resulting 30-liter suspension was poured through three superposed $200-\mu \mathrm{m}$ sieves. The sieves were rinsed to collect debris and nematodes. Nematodes were then extracted from the debris using the modified Oostenbrink method for large nematodes (42). The nematodes were retained using three $200-\mu \mathrm{m}$ sieves. The final debris containing nematodes was rinsed with water and placed on a single KLEENEX tissue in a 1-mm sieve (diameter: $12 \mathrm{~cm}$ ) in a $14-\mathrm{cm}$ petri dish containing $100 \mathrm{ml}$ of water. Active nematodes were recovered in the bottom of the dish after $72 \mathrm{~h}$. Nematodes (adults and juveniles) were counted from the final suspension under a dissecting microscope.

Sampling design. Spatial distributions of nematodes were assessed at different periods: during October to November 2004 (vertical distribution) and May 2005 (horizontal distribution) in plots 1 and 2, and June 2005 (horizontal distribution) in plot 3. In plots 1 and 2, GFLV infection was previously detected in June 2004, on five to eight young leaves per plant, using an ELISA GFLV detection kit (Bioreba, Reinach, Switzerland). A glyphosate devitalization treatment, considered inoffensive for nematodes $(13,25)$, had been performed in September 2004, and the plants were uprooted in April 2005. Plot 3 was a growing grapevine block.

Vertical distribution of $\boldsymbol{X}$. index. In plot 1 , we selected a microplot $(8.4 \times 6.5 \mathrm{~m})$ with many GFLV-infected grapevine plants (Fig. 1A and B). Two 60-cm wide $\times 2-\mathrm{m}$ deep trenches were dug over the total length of the microplot with an excavating machine (along and across vine rows). Four smaller trenches were also made in the corners of the microplot (Fig. 1B). For the distribution of nematodes in the soil profile, 2-liter samples of undisturbed soil were recovered with a hand spade as follows: samples were 60 and $50 \mathrm{~cm}$ distant from each other along and across the vine rows, respectively, and this horizontal sampling was repeated separately in each of the vertical layers. In plot 2 , we selected a microplot $(5.5 \times 3.6 \mathrm{~m})$ also located in a place with many GFLV-infected grapevine plants. Three parallel trenches (60 cm wide, $2 \mathrm{~m}$ deep) were dug with an excavating machine as shown in Figure 1B. Eight 2-liter samples, separated along the row by $50 \mathrm{~cm}$ and located on the two sides of each trench, were collected in each of the soil layers. Physical soil characteristics and root structure were recorded for each plot.

Horizontal distribution of $X$. index and GFLV-infected plants at field scale in plots 1 and 2 . For both plots, the entire field surface was considered (Fig. 1A). Samples were regularly collected within squares of approximately $150 \mathrm{~m}^{2}(10 \times 15 \mathrm{~m}$ grid). Narrow, 1-m-deep trenches were dug with an excavating machine and a single 2-liter sample per trench was recovered by collecting the soil clods from the two sides, at 0.5 to $0.8 \mathrm{~m}$ depth.

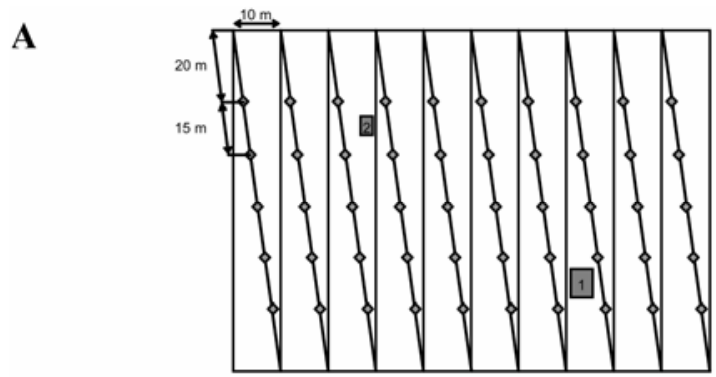

B

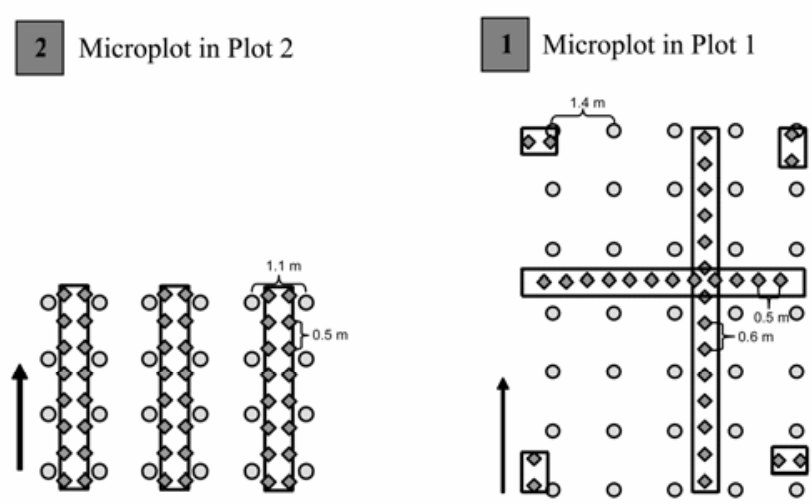

C

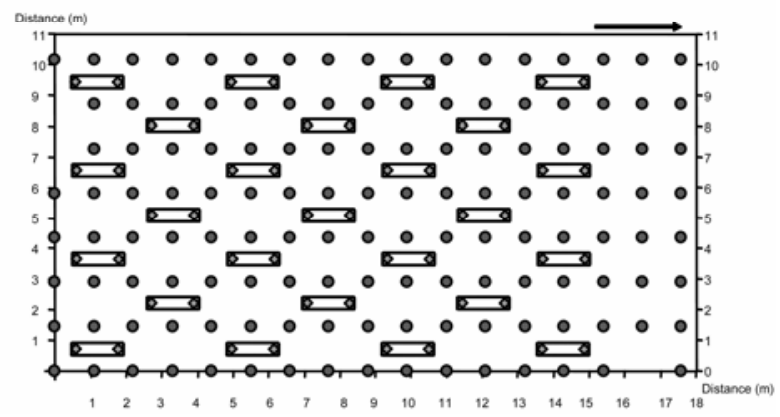

Fig. 1. Sampling scheme used to investigate the spatial distribution of Xiphinema index. Circles indicate the position of grapevine plants, diamonds indicate the sampling points, and arrows show the direction of vine rows. A, Sampling scheme for horizontal distribution at field scale, for plots 1 and 2 . Rectangles show the localization of microplots defined to study the vertical distribution in the Plots 1 and 2. B, Sampling scheme for vertical distribution in the microplots from the plots 1 and 2. For each sampling point, four samples (one per layer) were taken. C, Horizontal distribution sampling scheme for nematode and virus in plot 3. Rectangles show the localization of the trenches in which two samples were collected.

TABLE 1. Characteristics of the three plots

\begin{tabular}{llcccccc}
\hline Field & Location & Surface & Age (years) & Status & \multicolumn{1}{c}{ Variety } & Rootstock & \% Grapevine fanleaf virus-infected plants \\
\hline Plot 1 & Saint Emilion & $1.35 \mathrm{ha}$ & 44 & End of crop & Merlot, Cabernet Franc & $3309 \mathrm{C}$ & 50.5 \\
Plot 2 & Margaux & $1 \mathrm{ha}$ & 77 & End of crop & Petit Verdot & Riparia & 88 \\
Plot 3 & Pomerol & $180 \mathrm{~m}^{2}$ & 29 & Culture & Merlot, Cabernet Franc & 3309C & 32.3 \\
\hline
\end{tabular}


Horizontal distribution of $X$. index and GFLV-infected plants at a finer scale in plot 3 . The horizontal distribution of nematodes in plot 3 was monitored in June 2005, in a $10 \times 18 \mathrm{~m}$ rectangle containing 133 plants ( 8 rows $\times 16$ or 17 plants each). Twenty-five trenches (length, $1.5 \mathrm{~m}$; width, $0.3 \mathrm{~m}$; and depth, 1 $\mathrm{m})$ were dug with an excavating machine between grapevines rows (Fig. 1C). Two 2-liter samples of soil, one from each end, were collected from each trench, at a depth of 0.5 to $0.8 \mathrm{~m}$. Concurrently, five to eight young leaves per plant were collected and processed for ELISA virus detection as previously detailed.

Data analysis. The total number of nematodes was tested against the plots (plots 1 and 2) and layers by using a generalized linear model assuming a Poisson error variable (Quasi-Poisson error in case of over-dispersed data) and a log link function (27). All computations were done with the $\mathrm{R}$ software package, version 2.6.1. (31). Pairwise comparisons between layers were performed with the function 'esticon' in the 'doBy' package (Author: Søren Højsgaard). The variance-to-mean-ratios (dispersal indices = DI) were computed to test whether nematodes were uniformly (uniform distribution; DI $<1$ ), randomly (Poisson distribution; DI $\approx$ 1) or patchily (aggregated distribution; DI $>1$ ) distributed $(24$, 38). The spatial structure of nematode densities was determined with the autocorrelogram technique based on local Moran's Index (I). This technique permits testing the relation between nematode densities within each pair of sampling points and their Euclidean distance $(28,33,34)$. If I values are smaller for large than for small distance classes, the nematode densities are not independent from their geographical location (autocorrelated). For plot 3, the ordinary Kriging technique was applied to nematode densities observed at each sampling point to map their spatial distribution and to visually depict areas of high densities $(23,26)$. This technique extrapolates the densities of the individuals at unsampled points from those calculated at sampled points. Exponential or

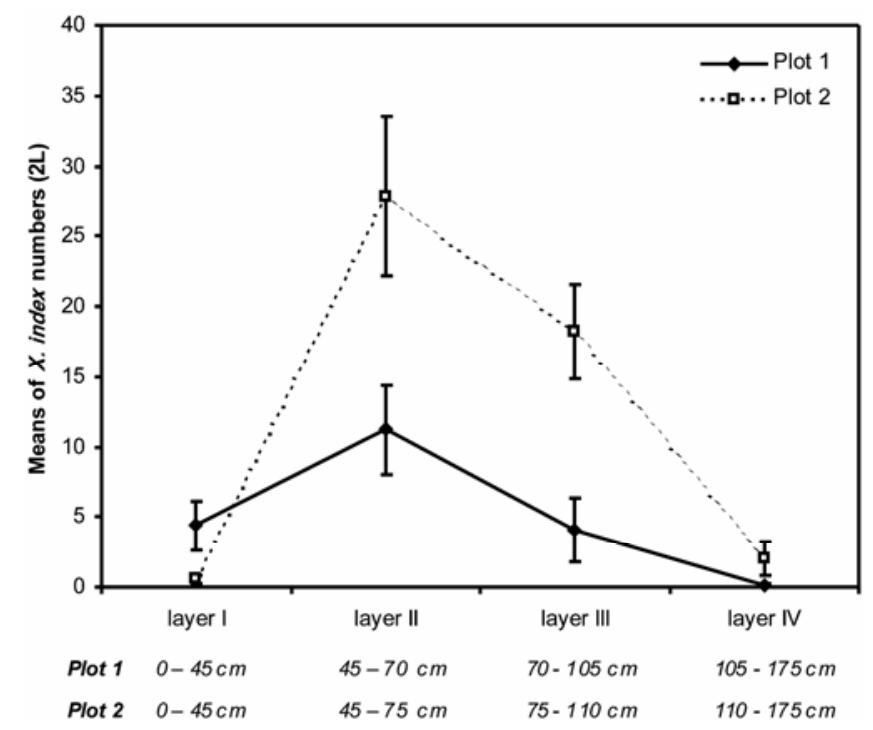

Fig. 2. Vertical distribution of Xiphinema index numbers in plots 1 and 2 (means \pm standard error). spherical models were fitted to the data using a nonlinear least squares method. The model minimizing the Akaike information criterion (AIC) was then retained for Kriging. Calculations of Moran's index and Kriging were performed with R, version 2.6.1. (31), using the method described in Fievet et al. (17). To determine whether the spatial distribution of GFLV-infected grapevine individuals was correlated with that of nematodes, we assessed the levels of association between both virus and nematode distributions within the grapevine field using a G-test, which consisted of comparing the numbers of co-occurrences of "GFLV-infected grapevine plants" and "nematodes" with those expected under the hypothesis of independence. The presence of nematodes under GFLV-infected grapevines plants was determined using the map of densities obtained from the ordinary Kriging technique.

\section{RESULTS}

Vertical distribution of $X$. index. Soil type and profile. In plot 1, four soil layers were observed (I: 0 to 45 , II: 45 to 70 , III: 70 to 105 , and IV: 105 to $175 \mathrm{~cm}$ deep), with a permanent water table below layer IV. Soil texture and soil type were determined from Taylor and Brown (35). Layers I (wet) and II (dry and compact) were sandy loam soil. Layers III and IV were, respectively, a sandy soil and a sandy-clay loam soil. Stones of all sizes (up to $8 \mathrm{~cm}$ diameter) were abundant in all layers with higher numbers in layers III and IV. In plot 2, four soil layers were also present (I: 0 to 45 , II: 45 to 75 , III: 75 to 110 and IV: 110 to 175 $\mathrm{cm}$ deep) with the water table below layer IV as well. During observations (October to November 2004), all layers were very wet due to recent rainfalls. Layers I and II were sandy loam soil, but layer II contained pieces of heavy clay around which a clustering of fine roots was sometimes observed. Layers III and IV (very similar to layer IV in plot 1) were sandy clay loam soil. As in plot 1, stones, although present in all layers, were more abundant in layers III and IV.

Vine root system. In plot 1, layers I and II contained mainly thick roots. Some small clusters of fine rootlets (presumably adequate for Xiphinema feeding) were present at the bottom of the ploughing zone and at the transitions between layers I and II, II and III, and III and IV. Most fine roots were observed within layers II and III and were absent in layer IV, probably because of submersion by the water table up to layer III every winter. In plot 2 , thin roots of vine were present from the lower part of layer I through the entire layer II, with a clustering of thin roots at their transition. Layer III contained fewer roots than the previous ones, and a clustering of thin roots was sometimes observed between layers II and III. A few thin roots were sometimes observed in layer IV.

Vertical distribution of $X$. index (Fig. 2). We counted a mean of $5 \pm 1.1 X$. index per 2-liter sample for plot 1 , and a mean of $14.2 \pm 2.2$ for plot 2 (Table 2), and a mean of $10.1 \pm 2.04$ and 22 \pm 3.1 individuals per 2-liter sample in plots 1 and 2, respectively, if only nematode containing samples are considered. There were significantly more nematodes in plot 2 than in plot 1 (GLM; $\chi^{2}=$ 14.127, df $=1, P<0.001)$. In both plots, nematodes were not homogeneously distributed within layers (GLM; $\chi^{2}=62.366, \mathrm{df}=$ $3, P<0.001)$. Globally, nematode densities were approximately

TABLE 2. Summary statistics of Xiphinema index numbers in plots 1,2 , and 3

\begin{tabular}{|c|c|c|c|c|c|}
\hline \multirow[b]{2}{*}{ Statistics } & \multicolumn{2}{|c|}{ Vertical distribution } & \multicolumn{3}{|c|}{ Horizontal distribution } \\
\hline & Plot 1 & Plot 2 & Plot 1 & Plot 2 & Plot 3 \\
\hline Total sampling points & 34 & 47 & 50 & 50 & 50 \\
\hline Mean nematode numbers (per 2L) & 5 & 14.2 & 4.9 & 38.7 & 12.2 \\
\hline Variance & 158.6 & 742.5 & 153.6 & 4,321 & 321.3 \\
\hline Extreme values & $0-64$ & $0-184$ & $0-68$ & $0-276$ & $0-73$ \\
\hline Variance/mean DI ${ }^{\mathrm{a}}$ & 31.7 & 52.3 & 31.34 & 111.7 & 26.3 \\
\hline
\end{tabular}

${ }^{a}$ Dispersal indice (DI) is the variance-to-mean ratio. 
the same between layers 1 and 4 (confidence interval; level = $0.95 ; t=0.787$, df $=282, P=0.432$ ). Layers 2 and 3 harbored higher nematode densities than layer 1 (confidence interval; level $=0.95 ; t=-5.026$ and $t=-3.753$ respectively, $\mathrm{df}=282, P<$ 0.001 ) and than layer 4 (confidence interval; level $=0.95 ; t=$ 3.198 and $t=2.641$, respectively, $\mathrm{df}=282, P<0.001$ ). In both plots, layer 2 had the highest nematode densities (confidence interval; level $=0.95 ; t=2.318, \mathrm{df}=282, P<0.05$ ).

Horizontal distribution of $X$. index and GFLV-infected plants at the field scale (plots 1 and 2). Previous tests for GFLV detection, performed in June 2004 before pulling out the plants from both plots, showed that 50.5 and $88 \%$ out of the 286 and 244 total plants, for plot 1 and plot 2 respectively, were infected and that GFLV infection had spread all over both fields, without marked patches of disease. In the horizontal distribution studied in May 2005, 36 and 11 out of the 50 samples were $X$. index free in plots 1 and 2, respectively (Fig. 3). We counted a mean of $4.9 \pm$ 2.0 and $38.7 \pm 9.3$ individuals per 2-liter sample in plots 1 and 2 , respectively (Table 2), and a mean of $14.5 \pm 4.7$ and $49.6 \pm 11.3$ individuals per 2-liter sample in plots 1 and 2, respectively, when considering only nematode positive samples. We observed an aggregative spatial pattern of nematode density (Fig. 3) with DI values of $31.3(P<0.001)$ for plot 1 and $111.7(P<0.001)$ for plot 2. The mean distance between two sampling points was 54.13 $\pm 0.52 \mathrm{~m}$ in plot 1 and $39.80 \pm 0.43 \mathrm{~m}$ in plot 2 . For both plots, Moran's indices were not significant for most distance classes (Fig. 4A), suggesting there is no neighborhood structure of nematode densities.

A

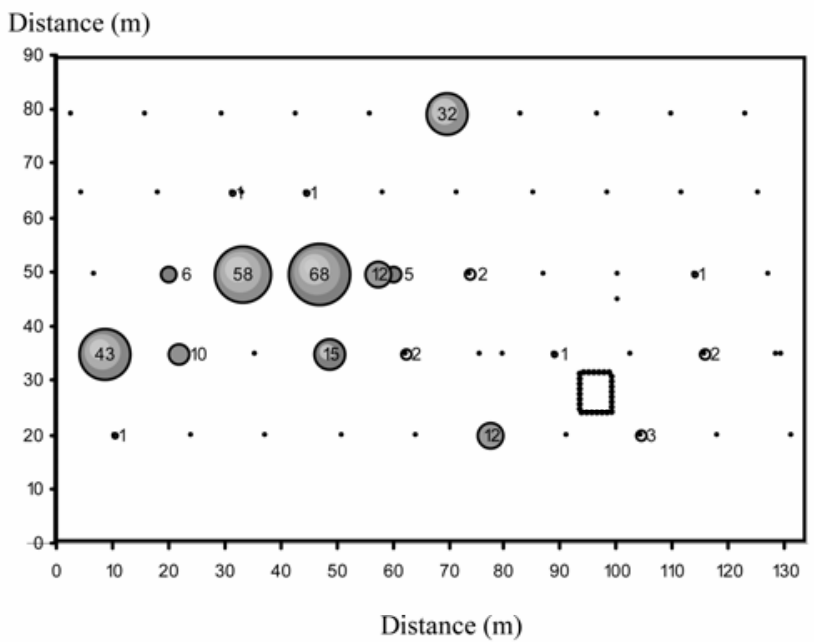

B Distance (m)

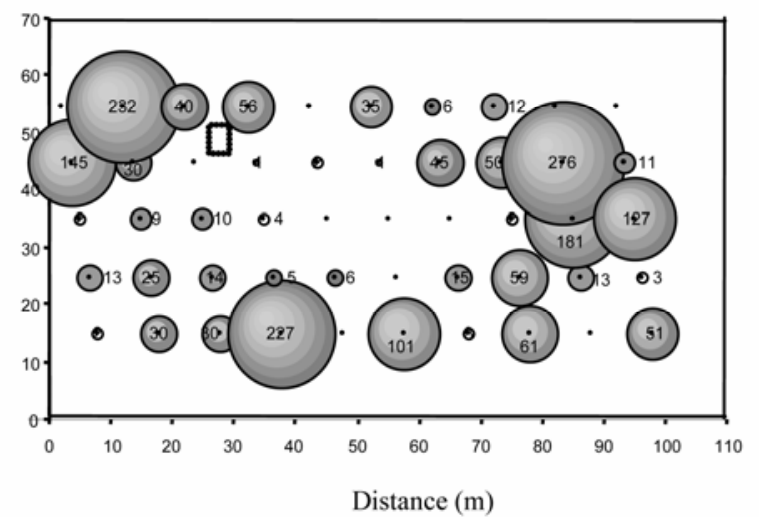

Fig. 3. Horizontal distribution of Xiphinema index at the field scale in plots A, 1 and $\mathbf{B}, 2$. Values within circles indicate the numbers of nematode individuals recovered per 2-liter soil sample. Points indicate the 50 sampling points. Rectangles in dashed lines show the localization of the vertical distribution sampling in the plots 1 and 2 .
Horizontal distribution of $X$. index at a finer scale (plot 3 ). Sixteen samples out of 50 were $X$. index-free. We counted a mean of $12.2 \pm 2.5 X$. index per 2-liter sample (Table 2) and observed an aggregative spatial pattern of nematode density with a DI value of $26.3(P<0.001)$. For only samples in which we detected nematodes, we counted a mean of $17.9 \pm 3.3$ individuals per 2-liter sample. The mean distance between two sampling points was $6.84 \pm 0.07 \mathrm{~m}$. Moran's indices, significant for most distance classes (Fig. 4B), indicate a significant neighborhood structure with nematode patches of 6 to $8 \mathrm{~m}$ diameter. The cartography of $X$. index by ordinary Kriging shows two patches of nematodes, with different nematode densities and suggests an isotropic diffusion of individuals and the development of secondary patches (Fig. 5).

Spatial distribution of GFLV. Most infected grapevine plants were observed in the left corner of the plot 3 (Fig. 5), with a decreasing gradient of infected plants in direction of the opposite corner. A significant difference between the observed numbers of co-infestations "virus-infected plants/nematodes" and those expected by chance was observed $\left(\chi^{2}>10 \mathrm{e} 5, P<0.001\right)$. This indicates dependent occurrence of GFLV-infected grapevine plants and nematodes, as suggested in Figure 5.

\section{DISCUSSION}

Our studies, based on nematode- and virus-infected grapevine blocks in Bordeaux vineyard, are the first to consider, simultaneously and at different spatial scales, horizontal and vertical distributions of $X$. index. A further original feature of our approach is connecting horizontal distributions of nematode individuals and virus-infected grapevine plants.

Population functioning of nematode and virus in agroecosystems, spatial arrangements of crop fields, and crop management
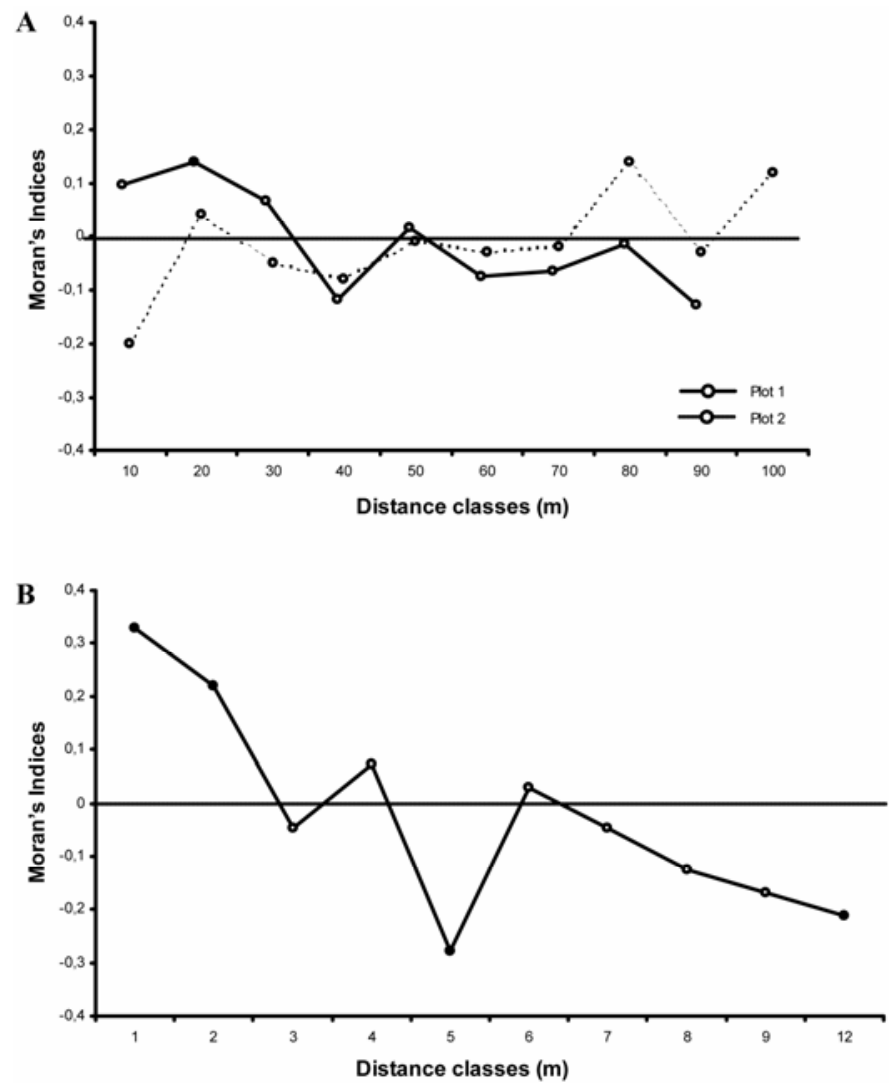

Fig. 4. Correlograms calculated from numbers of Xiphinema index individuals in 2-liter samples in $\mathbf{A}$, Plots 1 and 2 and $\mathbf{B}$, Plot 3. It represents the evolution of the Moran's indices (I). Black points indicate a significant correlation at $P<0.05$. 
practices are major determinants of the population dynamics of many important pest species (22). For example, Gavassoni et al. $(18,19)$ have shown the influence of tillage and crop rotation on the population density and spatial pattern of Heterodera glycines. Here, crop practices seem to influence the spread of the virus via its vector, i.e., the nematode. Virus and nematode are not independently distributed within fields and the population functioning of the virus depends on nematode. The nematode distribution suggests (i) an initial introduction of nematodes in primary patches and then (ii) the onset and development of secondary patches, preferentially in the direction of vine rows. This could be an effect of tillage during mechanical weeding, which is performed exclusively in the direction of vine rows. But future studies should concentrate on pedological characteristics, particles size, roots density, moisture, etc., that could explain nematode distribution and dispersal processes. Finally, this work confirms previous results suggesting a major role of agricultural machinery in passive dispersion of nematodes $(6,18,19,36,44,46,47)$.

Our results revealed a strong spatial pattern of nematode densities linked to spatial distribution of GFLV-infected grapevine plants. At a community level, agricultural machinery is presumably also a determinant in virus spread. The transfer of soil containing either viruliferous nematode individuals (alone or associated with viable roots of uprooted grapevines) or nonviruliferous nematodes associated with viable roots of uprooted GFLV-infected grapevines, may allow GFLV dissemination over short and probably long distances.

But even if most infected grapevines are detected in areas with the highest nematode densities, GFLV-infected vine plants were also found in areas where no nematodes were detected. This could result from our sampling scheme. Indeed, samples were limited to 2 -liter soil volumes, each representing approximately $4 \mathrm{~m}^{2}$. Although they were collected in the most nematode-populated soil layers II and III, they are an incipient fraction (1/600) of the total soil volume contained between the depth of 50 and $80 \mathrm{~cm}(0.3 \times$ $4 \mathrm{~m}^{2}=1.2 \mathrm{~m}^{3}=1,200$ liters). Consequently, as virus can be transmitted from only a few nematodes (35), we could have missed them. Furthermore, grape roots can extend several meters from their mother plant. Roots of healthy grapevines may thus become infected by reaching a neighboring GFLV-infected zone with higher numbers of viruliferous individuals. The alternative is that nematode mortality occurred whereas virus persists within grapevine plants. Another explanation for nondetection of nematodes is that GFLV plant infections may not be due to field nematodes but may have occurred previously in the nursery during cutting, grafting, or rooting. Nevertheless, since certified plant material is produced under the severe rules of a prophylactic scheme, this should ensure that GFLV-infected nursery plants are very rare. Conversely, virus and nematode distributions also revealed the presence of $X$. index in locations of plot 3 for which grapevine plants were found non-GFLV-infected. Such plants were mainly located close to the secondary patch of nematode dispersal (Fig. 5). This may be due to a delayed viral contamination of the plant leaves as nematode individuals first transmit the virus to the roots and viral migration to the aerial part needs a supplementary time. A complementary hypothesis is that most individuals in this frontal part of the secondary patch have become nonviruliferous after their dispersal (from the primary patch) because of molting. Such individuals might require growing roots, from far GFLV-infected plants, reach them to get the virus, retain and transmit it to the closest plants which they preferentially feed on.

Consequences for control and sampling strategies of $X$. index populations. Need for 3D control strategies. Results from vertical distribution of $X$. index shed light on the limited efficiency of chemical control strategies against this pest. Vertical distributions of $X$. index were assessed in two fields in Bordeaux vineyard. Soil types and root profiles were very similar in plots 1 and 2 . In both, all layers had comparable particle sizes, except for the third layer, which was composed of sandy soil in plot 1 and sandy clay loam in plot 2 . For both plots, the highest densities of $X$. index occurred at $40-$ to $110-\mathrm{cm}$ depth, where many thin grape roots were present. These results are consistent with those obtained in the Champagne region of France (14). The Champagne results have also showed nematode locations in deep soil layers

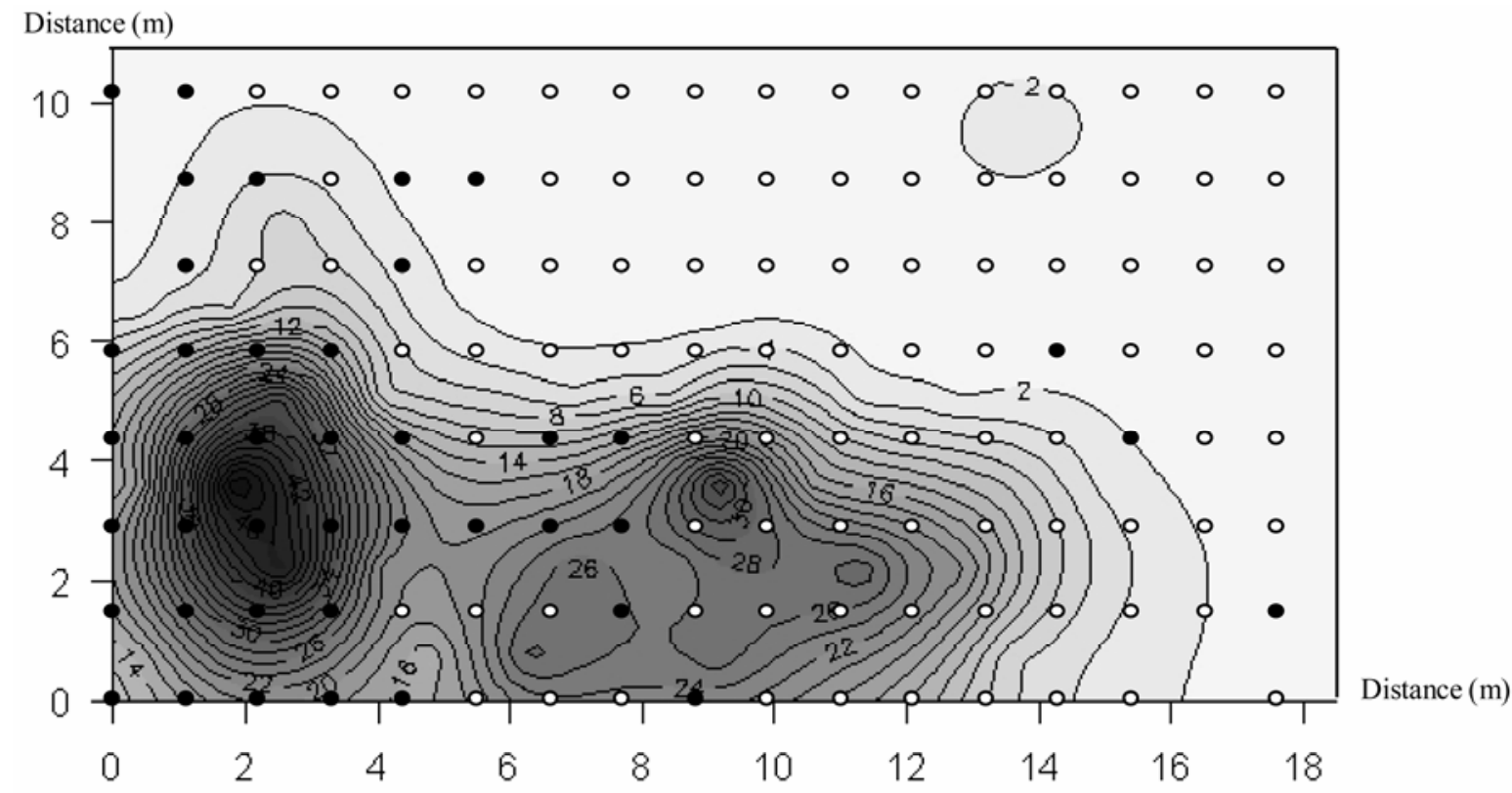

- Grapevine plant infected by GFLV (ELISA Test +)

○ Healthy grapevine plant (ELISA Test -)

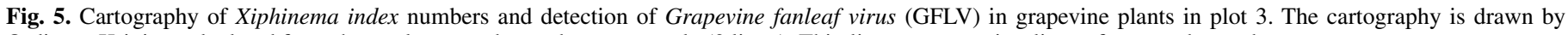
Ordinary Kriging calculated from the total nematode number per sample (2 liters). Thin lines represent isoclines of nematode numbers. 
containing most of the thin grape roots. The ability of $X$. index individuals to survive and remain viruliferous in the soil for at least 4 years has been shown recently (12). This information, combined with the location of nematodes in deep soil layers described here, may explain why nematicides have limited efficiency against $X$. index, given that they can not reach such depths. Thus, the main challenge of alternative control methods will be to reach those deep layers.

Improvement of sampling strategies. Three dimensional $X$. index distribution has to be taken into account in nematodes sampling strategies. Our data clearly showed that the superficial layers harbor no (plot 2) or fewer (plot 1) nematode individuals than do deeper ones. To accurately estimate $X$. index nematodes densities within fields, sampling would need to be performed at a depth of 50- to $80-\mathrm{cm}$, within soil layers containing the highest density of thin grapevine roots.

The choice of the sampling strategy affects the spatial pattern of nematode distribution that is revealed. Indeed the appropriate selection of a sampling mesh is crucial for quantifying spatial patterns in any ecological data $(7,9,10,29)$ and a spatial pattern revealed at a certain scale may disappear at another. This choice becomes crucial as cost associated with a sampling point increases. In Bordeaux vineyards, soil sampling methods need heavy material (excavating machine) to dig in the soil, are very time consuming, and are destructive for the field. So, our sampling strategy has been conducted to minimize associated cost of a sampling point and maximize information about spatial distribution of $X$. index. At the field scale, no distance class lower than $15 \mathrm{~m}$ was represented in our data set. While enough to localize spots of highest nematode densities, 50 samples per hectare were insufficient to infer strong conclusions about population functioning at this scale.

Sampling may gain in accuracy by increasing the number of sampling points per soil surface. This can be done without larger sampling cost by choosing smaller plot surfaces (and thus higher sampling density). For $X$. index, one sample per $4 \mathrm{~m}^{2}$ (the finer scale used here) is sufficient to reveal a significant aggregative pattern and a significant neighborhood structure with large patches of 6- to 8-m diameter. This is consistent with the limited capacities of active dispersal of the nematode. To study the spatial structure of $X$. index populations, the sampling scheme would consider an intermediate scale in highly infested areas revealed by the highest prevalence of GFLV-infected plants. Another strategy should be to stratify sampling by increasing the sampling effort in highly infested areas while decreasing effort in the part where low nematode densities may be suspected.

Because an excavating machine is needed, random sampling is difficult to define. Random sampling allows us to consider more various distance classes than regular sampling schemes and could be very useful in diagnostic sampling at the field scale. To accurately estimate densities while minimizing sampling effort, an adaptive cluster sampling may be done. In adaptive cluster sampling, $n$ samples are taken using simple random sampling, and additional samples are taken at locations where measurements exceed a threshold value. These locations can be previously determined by screening the level of GFLV-infected plants in the different parts of the field. Adaptive cluster sampling tracks the selection probabilities for later phases of sampling so that an unbiased estimate of the population mean can be calculated despite oversampling of certain areas.

This study considered three dimensions to determine how nematode populations used available space in grapevine field and how it influenced virus spread. However, an epidemic is a temporal process and, in this specific case, can be governed by factors acting in four dimensions (2D space, depth and time). It would be thus worthwhile simultaneously considering the time to describe both dynamics of the nematode and of the virus. Indeed, their population dynamics could be asynchronized. There is no evi- dence that virus spread is linked to some 'optimal' nematode densities. Since only one viruliferous nematode individual is sufficient to infect a grapevine plant, virus spread could be governed by migration front, i.e., where the nematode densities are the lowest. Last, our results, and particularly the identification of the relevant sampling scale to describe $X$. index distribution (spatial delimitation of populations and measures of population density and thus of population size), provide a valuable tool for any field study of this nematode, especially for population dynamics and population genetics studies that are needed to elaborate efficient control methods against this pest.

\section{ACKNOWLEDGMENTS}

We thank the estates and their vineyard managers that have funded this research. We thank B. Chauvin for his help during the sampling, L. Valente for providing valuable corrections on earlier version of this manuscript, and two anonymous referees for their helpful comments.

\section{LITERATURE CITED}

1. Aballay, E., Sepulveda, R., and Insunza, V. 2004. Evaluation of five nematode-antagonistic plants used as green manure to control Xiphinema index Thorne et Allen on Vitis vinifera L. Nematropica 34:45-51.

2. Abawi, G. S., and Widmer, T. L. 2000. Impact of soil health management practices on soilborne pathogens, nematodes and root diseases of vegetable crops. Appl. Soil Ecol. 15:37-47.

3. Andret-Link, P., Laporte, C., Valat, L., Ritzenthaler, C., Demangeat, G., Vigne, E., Laval, V., Pfeiffer, P., Stussi-Garaud, C., and Fuchs, M. 2004. Grapevine fanleaf virus: Still a major threat to the grapevine industry. J. Plant Pathol. 86:183-195.

4. Been, T. H., and Schomaker, C. H. 2006. Distribution patterns and sampling. Pages 302-326 in: Plant Nematology. R. N. Perry and M. Moens, eds. CAB International, St. Albans, UK.

5. Bello, A., Arias, M., Lopez-Perez, J. A., Garcia-Alvarez, A., Fresno, J., Escuer, M., Arcos, S. C., Lacasa, A., Sanz, R., Gomez, P., Diez-Rojo, M. A., Buena, A. P., Goitia, C., de la Horra, J. L., and Martinez, C. 2004. Biofumigation, fallow, and nematode management in vineyard replant. Nematropica 34:53-64.

6. Boag, B. 1985. The localized spread of virus-vector nematodes adhering to farm machinery. Nematologica 31:234-235.

7. Boag, B., Neilson, R., and Brown, D. J. F. 1992. Nematode sampling and prediction. Nematologica 38:459-465.

8. Brown, D. J. F., and Weischer, B. 1998. Specificity, exclusivity and complementarity in the transmission of plant virus parasitic nematodes: An annotated terminology. Fund. Appl. Nematol. 21:1-11.

9. Campbell, C. L., and Madden, L. V. 1990. Spatial aspects of plant disease epidemics I: Dispersal gradients and long-range transport. In: Introduction to Plant Disease Epidemiology. C. L. Campbell and L. V. Madden, eds. John Wiley \& Sons, New York.

10. Campbell, C. L., and Madden, L. V. 1990. Spatial aspects of plant disease epidemics II: Analysis of spatial pattern. In: Introduction to Plant Disease Epidemiology. C. L. Campbell, and L. V. Madden, eds. John Wiley \& Sons, New York.

11. Cohn, E. 1969. The occurrence and distribution of species of Xiphinema and Longidorus in Israël. Nematology 15:179-192.

12. Demangeat, G., Voisin, R., Minot, J. C., Bosselut, N., Fuchs, M., and Esmenjaud, D. 2005. Survival of Xiphinema index in vineyard soil and retention of Grapevine fanleaf virus over extended time in the absence of host plants. Phytopathology 95:1151-1156.

13. Descottes, A., and Moncomble, D. 1995. Lutte contre le court-noué. Le vigneron champenois 9:20-24.

14. Esmenjaud, D., Walter, B., Valentin, G., Guo, Z. T., and Cluzeau, D. 1992. Vertical-distribution and infectious potential of Xiphinema index (Thorne et Allen, 1950) (Nematoda, Longidoridae) in fields affected by grapevine fanleaf virus in vineyards in the Champagne region of France. Agronomie 12:395-399.

15. Esmenjaud, D. 2000. Les nématodes de la vigne. In: Ravageurs de la Vigne. J. Stockel, ed. E. Féret, Bordeaux, France.

16. Feil, H., Westerdahl, B. B., Smith, R. J., and Verdegaal, P. 1997. Effects of seasonal and site factors on Xiphinema index populations in two California vineyards. J. Nematol. 29:491-500.

17. Fievet, V., Dedryver, C. A., Plantegenest, M., Simon, J. C., and Outreman, Y. 2007. Aphid colony turn-over influences the spatial distribution of the grain aphid Sitobion avenae over the wheat growing season. Agric. Forest Entomol. 9:125-134.

18. Gavassoni, W. L., Tylka, G. L., and Munkvold, G. P. 2001. Relationships 
between tillage and spatial patterns of Heterodera glycines. Phytopathology 91:534-545.

19. Gavassoni, W. L., Tylka, G. L., and Munkvold, G. P. 2007. Effects of tillage practices on dissemination and spatial patterns of Heterodera glycines and soybean yield. Plant Dis. 91:973-978.

20. Harris, A. R. 1979. Seasonal populations of Xiphinema index in vineyard soils of north-eastern Victoria, Australia. Nematologica 25:336-347.

21. Hewitt, W. B., Raski, D. J., and Goheen, A. C. 1958. Nematode vector of soil-borne fanleaf virus of grapevines. Phytopathology 48:586-595.

22. Kennedy, G. G., and Storer, N. P. 2000. Life systems of polyphagous arthropod pests in temporally unstable cropping systems. Annu. Rev. Entomol. 45:467-493.

23. Krige, D. G. 1966. Two-dimensional weighted moving average trend surfaces for ore-evaluation. J. S. Afr. I. Min. Metal. 66:13-38.

24. Madden, L. V., and Hughes, G. 1995. Plant-disease incidence-Distribution, heterogeneity, and temporal analysis. Annu. Rev. Phytopathol. 33:529-564.

25. Magnien, C. 1998. Lutte contre le court-noué, La dévitalisation des ceps avant 1 'arrachage: Une mesure préventive d'un grand intérêt. Phytoma-La défense des Végétaux. 510:77-92.

26. Matheron, G. 1963. Principles of geostatistics. Econ. Geol. 58:1246-1266.

27. McCullagh, P., and Nelder, J. A. 1989. Generalized Linear Models. Chapman and Hall, New York.

28. Moran, P. A. P. 1950. Notes on continuous stochastic phenomena. Biometrika 37:17-23.

29. Perry, J. N., Liebhold, A. M., Rosenberg, M. S., Dungan, J., Miriti, M., Jakomulska, A., and Citron-Pousty, S. 2002. Illustrations and guidelines for selecting statistical methods for quantifying spatial pattern in ecological data. Ecography 25:578-600.

30. Quader, M., Riley, I. T., and Walker, G. E. 2003. Spatial and temporal distribution patterns of dagger (Xiphinema spp.) and root lesion (Pratylenchus spp.) nematodes in a South Australian vineyard. Australas. Plant Pathol. 32:81-86.

31. R Development Core Team. 2006. R: A language and environment for statistical computing. R Foundation for Statistical Computing, Vienna, Austria.

32. Raski, D. J., Goheen, A. C., Lider, L. A., and Meredith, C. P. 1983. Strategies against grapevine fanleaf virus and its nematode vector. Plant Dis. 67:335-339.

33. Sokal, R. R., and Oden, N. L. 1978. Spatial autocorrelation in biology 1. Methodology. Biol. J. Linn. Soc. 10:199-228.

34. Sokal, R. R., and Oden, N. L. 1978. Spatial autocorrelation in biology 2. Some biological implications and four applications of evolutionary and ecological interest. Biol. J. Linn. Soc. 10:229-249.
35. Taylor, C. E., and Brown, D. J. F. 1997. Nematode vectors of plant viruses. In: Nematode Vectors of Plant Viruses. CAB International, Wallingford, UK.

36. Taylor, C. E., Brown, D. J. F., Neilson, R., and Jones, A. T. 1994. The persistence and spread of Xiphinema-diversicaudatum in cultivated and uncultivated biotopes. Ann. Appl. Biol. 124:469-477.

37. Taylor, C. E., and Robertson, W. M. 1970. Sites of virus retention in the alimentary tract of the nematode vectors, Xiphinema diversicaudatum (Micol.) and $X$. index (Thorne and Allen). Ann. Appl. Biol. 66:375-380.

38. Taylor, L. R. 1961. Aggregation, Variance and the Mean. Nature 189:732735.

39. Taylor, L. R. 1984. Assessing and Interpreting the Spatial Distributions of Insect Populations. Annu. Rev. Entomol. 29:321-357.

40. Thomason, I. J., and McKenry, M. 1975. Chemical control of nematode vectors of plant viruses. Pages 423-439 in: Nematode Vectors of Plant Viruses. F. Lamberti, C. E. Taylor, and W. Seinhorst, eds. Plenum Press, New York.

41. Valloton, R., and Perrier, J. 1990. Les nématodes vecteurs de virus dans le vignoble de Suisse romande et du Tessin. Rev. Suisse Vitic. Arboric. Hortic. 22:53-58.

42. Verschoor, B. C., and de Goede, R. G. M. 2000. The nematode extraction efficiency of the Oostenbrink elutriator-cottonwool filter method with special reference to nematode body size and life strategy. Nematology 2:325-342.

43. Vuittenez, A., Legin, R., and Kuszala, J. 1969. Les viroses de la vigne. Les maladies des plantes. Journées françaises d'étude et d'information, Paris 5-7:577-578.

44. Wang, J., Donald, P. A., Niblack, T. L., Bird, G. W., Faghihi, J., Ferris, J. M., Jardine, D. J., Lipps, P. E., MacGuidwin, A. E., Melakeberhan, H., Noel, G. R., Pierson, P., Riedel, R. M., Sellers, P. R., Stienstra, W. C., Todd, T. C., Tylka, G. L., Wheeler, T. A., and Wysong, D. S. 2000. Soybean cyst nematode reproduction in the north central United States. Plant Dis. 84:77-82.

45. Weischer, B. 1975. Ecology of Xiphinema and Longidorus. Pages 291307 in: Nematode Vectors of Plant Viruses. F. Lamberti, C. E. Taylor, and W. Seinhorst, eds. Plenum Press, New York.

46. Workneh, E., Yang, X. B., and Tylka, G. L. 1999. Soybean brown stem rot, Phytophthora sojae, and Heterodera glycines affected by soil texture and tillage relations. Phytopathology 89:844-850.

47. Workneh, F., Tylka, G. L., Yang, X. B., Faghihi, J., and Ferris, J. M. 1999. Regional assessment of soybean brown stem rot, Phytophthora sojae, and Heterodera glycines using area-frame sampling: Prevalence and effects of tillage. Phytopathology 89:204-211. 